\title{
Increasing Adiponergic System Activity as a Potential Treatment for Depressive Disorders
}

\author{
Douglas Affonso Formolo ${ }^{1} \cdot$ Thomas Ho-Yin Lee $^{1} \cdot$ Suk-Yu Yau ${ }^{1,2}$ (B)
}

Received: 12 February 2019 / Revised: 9 May 2019 / Accepted: 10 May 2019 / Published online: 28 May 2019

(C) The Author(s) 2019

\begin{abstract}
Depression is the most devastating mental disorder and one of the leading contributors to the global medical burden. Current antidepressant prescriptions present drawbacks, including treatment resistance, delayed onset of treatment response, and side effects. The rapid and long-lasting antidepressant effect of ketamine has brought hope to treatment-resistant major depressive disorder patients. However, ketamine has undesirable addictive properties and is a drug of abuse. There is an urgent need, therefore, to develop novel pharmacological interventions that could be as effective as ketamine, but without its side effects. Adiponectin, a pleiotropic adipocyte-secreted hormone, has insulin-sensitizing and neurotrophic properties. It can cross the blood-brain barrier and target multiple brain regions where the adiponectin receptors are detected. Emerging evidence has suggested that adiponectin and the adiponectin receptor agonist, AdipoRon, could promote adult neurogenesis, dendritic and spine remodeling, and synaptic plasticity in the hippocampus, resulting in antidepressant effects in adult mice. By summarizing the most recent clinical and animal studies, this review provides a timely insight on how modulating the adiponergic system in the hippocampus could be a potential therapeutic target for an effective and fast-acting antidepressant response.
\end{abstract}

Keywords Adiponectin · Adiponectin receptors $\cdot$ AdipoRon $\cdot$ Hippocampus $\cdot$ Depression $\cdot$ Neuroplasticity

Depression is the worldwide, leading cause of years lived with disability, accounting for almost $10 \%$ of the total disability in $2010[1,2]$. This devastating disorder imposes a huge economic burden on patients and the healthcare systems [3, 4]. Therapeutic effects of the currently available antidepressant treatments are limited considering their low response rates $(\sim$ $50 \%$ ) and delayed therapeutic effects $[5,6]$. The delayed antidepressant response is alarming due to an increased risk for

Douglas Affonso Formolo and Thomas Ho-Yin Lee contributed equally to this work.

Electronic supplementary material The online version of this article (https://doi.org/10.1007/s12035-019-01644-3) contains supplementary material, which is available to authorized users.

Suk-Yu Yau

sonata.yau@polyu.edu.hk

1 Department of Rehabilitation Sciences, Faculty of Health and Social Sciences, The Hong Kong Polytechnic University, 11 Yuk Choi Road, Hung Hom, Kowloon, Hong Kong S.A.R.

2 University Research Facility in Behavioral and Systems Neurosciences, The Hong Kong Polytechnic University, 11 Yuk Choi Road, Hung Hom, Kowloon, Hong Kong S.A.R. suicidal behavior during the first month of antidepressant treatment [7]. Also, about 20\% of the depressed patients remain treatment-resistant, failing to respond to at least four drug trials and two drug classes [4]. Among those, suicidal ideation increases from 6 to $15 \%$ and the average response rate is lowered to $36 \%$ [4]. With the unmet need for antidepressant treatments, there is an urge to develop novel antidepressant drugs.

Currently, depression is considered as a neurocognitive disorder with associated impairments in adult neurogenesis and neural circuits [8-10]. This emerging conceptualization of depression has guided the development of a novel class of antidepressants targeting structural and functional neuroplasticity. Ketamine, an $N$-methyl-D-aspartate (NMDA)-receptor antagonist [11], induces a rapid and long-lasting antidepressant response in treatment-resistant patients with major depressive disorder (MDD) [12]. It acts by increasing glutamatergic transmission [13], synaptogenesis [14], synaptic plasticity [15], and neurotrophic factor expression [16] in key brain regions mediating mood regulation, such as the prefrontal cortex (PFC) and the hippocampus. However, its side effects have limited its clinical application [17].

Adiponectin is an adipocyte-secreted hormone that can cross the blood-brain barrier. It can act on its specific receptors 
in the hypothalamus to increase food intake and decrease energy metabolism [18]. Besides, adiponectin receptors are also present in several brain regions, including the hippocampus and the medial PFC [19]. Notably, intracerebral (i.c.v.) recombinant adiponectin infusion promotes dendritic arborization, spinogenesis, and neurogenesis in the hippocampal dentate gyrus (DG) [20], modulates hippocampal synaptic plasticity $[21,22]$, and elicits antidepressant response in normal mice [19]. Remarkably, it was recently demonstrated that the systemic administration of AdipoRon, a selective agonist of adiponectin receptors, can elicit an antidepressant response in depressed mice [23]. AdipoRon can bypass the bloodbrain barrier [24], indicating its direct effect on the brain. The modulation of the adiponectin signaling pathways, therefore, has unmasked a novel antidepressant strategy.
In this review, we summarize the pieces of evidence showing the effects of the adiponergic system on modulating neuroplasticity in the central nervous system.

\section{Adiponectin}

Adiponectin is the most abundant plasma protein in the circulation. It is released by mature white adipocytes and takes up about $0.01 \%$ of the total plasma proteins in human [25]. Adiponectin circulates as a trimer, hexamer, and highmolecular weight multimers, which are the major forms in mammals (Fig. 1) [26, 27]. Still, only trimer and hexamer are permeable to the blood-brain barrier and their concentrations in the cerebrospinal fluid compared to serum levels are



Full-length adiponectin

$\sim 30 \mathrm{kDa}$


Fig. 1 Adiponectin structure and its receptors. A full-length adiponectin $(\sim 30 \mathrm{kDa})$ consists of a globular domain, a collagenous domain, a species-specific domain, and a signal peptide. Oligomerization facilitates the formation of the trimer, hexamer, and high-molecular weight (HMW)

adiponectin. Full-length adiponectin can undergo proteolytic cleavage, whose proteolytic fragment corresponds to the globular adiponectin. AdipoR1 has a greater affinity for the globular form, whereas AdipoR2 has a moderate affinity for both globular and full-length forms 
approximately 1- to 4000-fold [18]. There are two adiponectinspecific receptors identified: adiponectin receptor 1 (AdipoR1) and receptor 2 (AdipoR2) [28]. AdipoR1 and AdipoR2 have differential affinities for different adiponectin oligomeric forms. AdipoR1 has a greater affinity for the globular form, whereas AdipoR2 has a moderate affinity for both globular and fulllength forms [28]. AdipoR1 is highly expressed in brain structures like the hippocampus, the PFC, the amygdala, the hypothalamus, and the ventral tegmental area [18, 19, 29], whereas AdipoR2 is more restricted to regions such as the hippocampal DG [30] and hypothalamus [18].

Adiponectin acts on the liver, the muscle, the heart, the adipocyte, and the blood vessel with antidiabetic, anti-inflammatory, antiatherogenic, and cardiovascular protective properties [31-34]. In the brain, adiponectin promotes food intake through the activation of its receptors in the hypothalamus [18]. Paradoxically, increased adipocyte size does not increase adiponectin secretion in obesity [35, 36], mainly due to hypoxia, cellular inflammation, and nutrient deprivation in the oversized adipocytes. The increase in pro-inflammatory cytokines suppresses adiponectin synthesis, leading to hypoadiponectinemia. Noticeably, hypoadiponectinemia is observed in type 2 diabetes mellitus (T2DM) [37], in which the adiponectin level also correlates with the comorbid depressive symptom severity [38]. Metabolic and mood disorders are, therefore, intertwined by the adiponergic system.

\section{Changes in Peripheral Adiponectin Levels in Patients with Depression}

An association among peripheral adiponectin levels and MDD has been suggested in different populations and health conditions (Table 1). A study consisting of cross-sectional $(n=575)$ and longitudinal $(n=262)$ analyses has shown that current episode of MDD, symptom severity, and history of depression in middle-aged women were all linked to the low adiponectin levels over a 5-year follow-up [39]. In depressed women, the adiponectin levels were sharply reduced by $25 \%$ and remained low over a 24-h period when measured hourly [40]. The correlations between low adiponectin levels and depression severity were also shown in men [41] and elderly patients [42]. This adiponectin-depression relationship was briefly summarized by a recent meta-analysis, illustrating a significant

Table 1 Changes in peripheral adiponectin levels in patients with depression

\begin{tabular}{|c|c|c|c|c|c|}
\hline \multirow[t]{2}{*}{ Authors (year) (ref) } & \multirow[t]{2}{*}{ Study design } & \multicolumn{2}{|l|}{ Population } & \multicolumn{2}{|l|}{ Associations } \\
\hline & & $\operatorname{Sex}(n)^{\mathrm{a}}$ & Associated condition & Depression indices & Adiponectin levels \\
\hline Everson-Rose et al. (2018) [39] & Cross-sectional & $q(575)$ & - & $\begin{array}{l}\text { Current depression } \\
\text { Symptom severity } \\
\text { History of depression }\end{array}$ & $\downarrow$ \\
\hline Cizza et al. (2010) [40] & Case-control & $q(23)$ & - & $\begin{array}{l}\text { History of depression } \\
\text { Cumulative duration of depression }\end{array}$ & $\downarrow$ \\
\hline Leo et al. (2006) [41] & Case-control & 우 ठ $(32)^{\mathrm{b}}$ & - & $\begin{array}{l}\text { Current depression } \\
\text { Symptom severity }\end{array}$ & $\downarrow$ \\
\hline Diniz et al. (2012) [42] & Case-control & $\begin{array}{l}\text { or (37) } \\
\text { ô }(10)\end{array}$ & Elderly subjects & $\begin{array}{l}\text { Current depression } \\
\text { Symptom severity }\end{array}$ & $\downarrow$ \\
\hline Laake et al. (2014) [43] & Cross-sectional & $\begin{array}{l}\text { o }(793)^{\mathrm{c}} \\
\hat{\partial}(976)\end{array}$ & $\mathrm{T} 2 \mathrm{DM}$ & Current depression & $\downarrow$ (trend $p=0.09)$ \\
\hline Herder et al. (2017) [44] & Cross-sectional & $\begin{array}{l}\text { o }(55) \\
\delta(84)\end{array}$ & T1DM & Symptom severity & No association \\
\hline & & $\begin{array}{l}\text { o }(97) \\
\text { o }(198)\end{array}$ & $\mathrm{T} 2 \mathrm{DM}$ & Symptom severity & $\downarrow$ \\
\hline Herder et al. (2018) [38] & Cross-sectional & $\begin{array}{l}\text { o }(227) \\
\partial(162)\end{array}$ & T1DM & Symptom severity & No association \\
\hline & & $\begin{array}{l}\text { o }(88) \\
\text { o }(116)\end{array}$ & $\mathrm{T} 2 \mathrm{DM}$ & Symptom severity & $\downarrow$ \\
\hline Yang et al. (2018) [45] & Cohort & $\begin{array}{l}\text { of }(117) \\
\text { of }(138)\end{array}$ & Ischemic stroke & Poststroke depression at 3 months & $\downarrow$ at baseline \\
\hline Fábregas et al. (2016) [46] & Cohort & $\begin{array}{l}\text { o }(26) \\
\hat{O}(24)\end{array}$ & Hepatitis C & MDD at 3 months & $\downarrow$ at baseline \\
\hline Tunçel et al. (2016) [47] & Case-control & $\begin{array}{l}\text { o (23) } \\
\text { of (7) }\end{array}$ & Adolescents (11-18 y.o.) & Current depression & No association \\
\hline Rebelo et al. (2016) [48] & Cohort & 우 (177) & Pregnant women & Perinatal depression & No association \\
\hline
\end{tabular}

${ }^{\text {a }}$ Total $n$ number for cross-sectional and cohort studies, $n$ number of cases for case-control design

${ }^{\mathrm{b}}$ Individual numbers of males and females are not reported

${ }^{\mathrm{c}}$ From the total sample of 1769 subjects (male and female), 1227 were included in the analysis 
decrease in the adiponectin levels in depressed patients compared to controls, in both males and females [49].

Adiponectin is also known as an anti-inflammatory cytokine. Metabolic disorders and cardiovascular diseases are marked by altered adiponectin levels [50, 51]. Coincidentally, depression is often comorbid with these disease states [52]. A large cross-sectional study $(n=1227)$ reported a correlating trend $(p=0.09)$ of the reduced adiponectin levels in earlystage T2DM and the severity of depression [43]. This association was later confirmed by two other studies, in which both high molecular weight to total adiponectin ratio [44] and total adiponectin concentrations [38] were correlated with the severity of depression in T2DM, but not in T1DM. In ischemic stroke patients, lower adiponectin levels at admission increased three times the risk of developing post-stroke depression [45]. In hepatitis $\mathrm{C}$ patients, higher adiponectin levels were associated with a lower incidence of MDD [46].

Interestingly, in consonance with the heterogeneity of depressive disorders, peripheral adiponectin levels might not be a ubiquitous biomarker for all depressive states. Depressed patients at the adolescent age ranging from 11 to 18 years old displayed comparable adiponectin levels to healthy agematched controls [47]. Additionally, adiponectin levels increased along with the pregnancy and the postpartum period, but with no correlation with the incidence of depressive symptoms [48]. This idea is also illustrated in rodent studies using different depressed animal models. Mice subjected to chronic unpredictable mild stress [53] or chronic corticosterone administration in drinking water $[23,54]$ did not reduce peripheral levels of adiponectin. However, the depressed mouse model induced by chronic social defeat stress had a signficant reduction in peripheral adiponectin levels, which was inversely correlated to the increased severity of depressive behavior $[19,55]$. These differences in rodent studies are likely due to the variations in the paradigms used for inducing depressivelike behaviors.

In summary, the evidence so far has suggested that decreased peripheral adiponectin levels can potentially be linked to major depressive disorder and depression co-morbid with some metabolic and cardiovascular disorders.

\section{Central and Peripheral Modulations of the Adiponergic Pathway on Antidepressant Effects}

The effects of antidepressant treatments over peripheral adiponectin levels are controversial in clinical studies. A short treatment period of 4 to 5 weeks by several classes of antidepressant drugs did not largely affect $[47,56,57]$, but with chances of reducing [58], adiponectin levels in depressive patients. On the other hand, MDD-remitted patients who had undergone selective serotonin reuptake inhibitor (SSRI) or serotonin-norepinephrine reuptake inhibitor (SNRI) treatments for at least 6 months showed increased levels of adiponectin and decreased levels of tumor necrosis factor alpha (TNF- $\alpha)$ when compared to healthy, matched controls [59]. Nonetheless, the improvements in depressive symptoms after long-term non-pharmacological, behavioral-cognitive therapy for T1DM and T2DM with comorbid depression and distress were not associated with increased adiponectin levels in the 12-month follow-up [60]. The fact that adiponectin is the most abundant plasma protein may hinder the detection of subtle changes in adiponectin levels, leaving only substantial alteration in the peripheral adiponectin levels as statistically detectable.

From another perspective, manipulation of peripheral adiponectin levels appears to elicit antidepressant effects in rodents. Rosiglitazone is a known effective antidiabetic agent, selectively agonizing the peroxisome proliferator-activated receptor gamma (PPAR $\gamma$ ), an upstream positive regulator of adiponectin [61]. Rosiglitazone cannot bypass the bloodbrain barrier. Systemic administration of rosiglitazone resulted in adiponectin-dependent antidepressant response in mice [55]. Moreover, systemic administrations of rosiglitazone within $24 \mathrm{~h}$ significantly increased peripheral adiponectin levels, which was necessary and sufficient to elicit an antidepressant response [55].

Besides, rodent studies have not only demonstrated the necessity of adiponectin in exercise- and environmentinduced antidepressant effects $[54,62,63]$ but also hint on the fact that increased adiponectin level in the central nervous system is associated with the antidepressant response. Particularly, voluntary wheel running for 14 days induced antidepressant effects in wild-type mice with increased adiponectin concentrations in the hippocampal DG, but not in the serum [60]. Similarly, environmental enrichment prevented anxiety and depression-like states in chronicallystressed mice with a four-fold increase in the cerebrospinal adiponectin levels, whereas plasma adiponectin levels remained unchanged [54]. These animal studies have shed light on the possible roles of the adiponergic system in inducing antidepressant effects [64, 65].

Importantly, direct activation of the central adiponergic pathway shows antidepressant effects. Central activation of the central adiponergic pathway by overexpressing adiponectin [62] or i.c.v. infusion of recombinant adiponectin consistently elicited antidepressant responses [19, 54, 63]. Strikingly, these animal studies have also shown that the adiponectin-induced antidepressant response was observable within hours.

AdipoRon is an orally active molecule that selectively agonizes the AdipoR1 and AdipoR2 [24]. As adiponectin, it exerts antidiabetic [24], anti-inflammatory [66], and cardiovascular protective properties [67]. AdipoRon can also bypass the blood-brain barrier [23] and act on brain regions like the 
hippocampus [30] and the ventral tegmental area [29]. Congruently, chronic administration of AdipoRon promoted hippocampal adult neurogenesis and results in antidepressant response in several animal models of depression [23]. Altogether, this data indicate that targeting adiponectin receptors and activating the adiponergic pathway are potential strategies for developing antidepressant drugs.

\section{Potential Mechanisms of the Antidepressant Effects of Adiponectin}

\section{Effects of Adiponectin on Neurogenesis}

In the adult mammalian brain, the sub-granular zone of the hippocampal DG contains a reservoir of neural stem cells. Granule neurons are continuously generated from these progenitors via adult hippocampal neurogenesis [68-73], which can integrate into the existing neural circuit [74-77]. Conventionally, depression is closely related to brain structure integrity [78], increased cellular stress [10], and increased dendritic and spine atrophy [10]. It was further postulated that adult hippocampal neurogenesis could antagonize stress and depression [79]; concurrently, antidepressant drugs are effective in promoting adult hippocampal neurogenesis [80-83]. Given so, the endeavor to reveal the role of adiponectin in structural plasticity were made thereafter.

Current opinion towards adiponectin is far more than an adipocyte-secreted endocrine hormone, but a neurotrophic factor, such that disruption of the adiponectin signaling pathway in the hippocampus impairs neurogenesis and cognitive functions $[20,62,84]$. The neurotrophic effect of adiponectin was first demonstrated in adult hippocampal stem cells, which expressed both AdipoR1 and AdipoR2 [85]. Adiponectin promoted proliferation, but not differentiation nor survival, in vitro via the $\mathrm{p} 38$ mitogen-activated protein kinases (MAPK)/glycogen synthase kinase (GSK)-3 $\beta / \beta$-catenin signaling pathway [85]. An adiponectin null mutant had reduced cell proliferation, differentiation, and survival in the hippocampus [20], whereas infusing adiponectin [20] or overexpressing adiponectin [62] in the mouse brain could promote cell proliferation in the hippocampal DG.

Physical exercise promotes adult neurogenesis in the hippocampus [86, 87]. It induces the release of neurotrophic factors such as the brain-derived neurotrophic factor (BDNF) [88, 89] and the insulin-like growth factor-1 (IGF-1) [90]. Rodents perform better in spatial recognition $[91,92]$ and have better executive functions [93] after exercise. In the study dissecting the role of adiponectin in exercise-induced antidepressant effect, the exercise-induced adult hippocampal neurogenesis was abolished in adiponectin-deficient mice [62]. The role of adiponectin as a mediator in exercise-promoted adult hippocampal neurogenesis is re-confirmed using streptozotocin to induce diabetes in adiponectin-deficient mice. Exercise could restore impaired hippocampal neurogenesis in wild-type diabetic mice, but not in adiponectin-deficient diabetic mice [84]. The neurogenic effects are possibly mediated by activating the AdipoR1/APPL1/AMPK pathway as shown by Yau and colleagues [62].

\section{Effects of Adiponectin on Dendritic Complexity and Spinogenesis}

Synaptic connections between neurons are predominantly tied up by dendritic spines. Spinogenesis is precisely regulated in response to stress, which consequently promotes rewiring of the neural network [94]. Depression is associated with dendritic spine pathology in the hippocampus [95-97]. Spinogenesis is often dysregulated in chronically stressed animals $[98,99]$. Antidepressants can reverse spine and dendrite atrophy in animal models of depression [100,101], leading to the idea that dendritic and spine atrophy could contribute to symptoms of depression $[9,102,103]$. Therefore, unraveling the role of adiponectin in spinogenesis can shed light on depression.

In addition to the data above, adiponectin promotes dendritic growth, arborization, and spine remodeling in the hippocampal DG [20]. Adiponectin null mutants had a reduced dendritic length, branching, and spine density of granule neurons, particularly in granule neurons generated during embryonic development [20], whereas i.c.v. infusion of adiponectin for a week promoted spinogenesis and dendritic complexity in adult-born granule neurons [20]. Moreover, upregulating AdipoR1/Nogo-66 receptor 1 (NgR1) signaling pathway by an adiponectin homolog, osmotin, could also enhance neurite outgrowth and synaptic complexity in the hippocampus in an Alzheimer's disease mouse model [104].

Adult hippocampal neurogenesis is impaired by stress and depression, whereas multiple rodent studies have demonstrated the neurogenic and antidepressant effects of adiponectin. The accumulated evidence has suggested that enhanced structural plasticity may be a critical factor in the adiponectin antidepressant properties.

\section{Effects of Adiponectin on Synaptic Plasticity}

Altered synaptic integrity underlies the structural changes, specifically reduced white matter integrity [78] and the mean hippocampal volume [105], reported in MDD patients. MDD patients have fewer spines in the PFC as well as reduced expression of genes participating in synaptic plasticity [106]. Such disturbance in synaptic integrity could deter synaptic transmission. Long-term potentiation (LTP) and long-term depression (LTD) are standard evaluations of synaptic plasticity [107]. Chronic stress, a conventionally accepted risk factor for depression [108], impairs hippocampal LTP [109, 110] and 
Table 2 Effects of adiponectin on synaptic plasticity

\begin{tabular}{|c|c|c|c|c|c|}
\hline $\begin{array}{l}\text { Authors (year) } \\
\text { (ref) }\end{array}$ & Subjects (age) & Methods & Site & $\begin{array}{l}\text { Electrophysiological } \\
\text { findings }\end{array}$ & Behavioral outcomes \\
\hline $\begin{array}{l}\text { Weisz et al. } \\
\text { (2017) [22] }\end{array}$ & $\begin{array}{l}\text { Adult and young mice } \\
\text { (C57BL/6J) }\end{array}$ & $\begin{array}{l}\text { Extracellular recording and } \\
\text { whole-cell patch clamping }\end{array}$ & CA1 & $\begin{aligned} & \downarrow \text { Paired-pulse ratio } \\
& \downarrow \text { Long-term potentiation } \\
& \downarrow \text { AMPA/NMDA ratio (on- } \\
& \text { ly in adult mice) }\end{aligned}$ & N/A \\
\hline $\begin{array}{l}\text { Sun et al. } \\
\text { (2018) [29] }\end{array}$ & $\begin{array}{l}\text { Adult mice } \\
\qquad(\mathrm{C} 57 \mathrm{BL} / 6 \mathrm{~J})\end{array}$ & $\begin{array}{l}\text { In vivo single-unit electrophysiological } \\
\text { extracellular recording }\end{array}$ & VTA & $\begin{array}{l}\downarrow \text { Population activity } \\
\downarrow \text { Average spontaneous } \\
\quad \text { firing rate }\end{array}$ & $\begin{array}{l}\text { Reduced the expression of } \\
\text { anxiety-like behaviors }\end{array}$ \\
\hline $\begin{array}{l}\text { Zhang et al. } \\
\text { (2017) [30] }\end{array}$ & $\begin{array}{l}\text { Adult mice } \\
\qquad(\mathrm{C} 57 \mathrm{BL} / 6 \mathrm{~J})\end{array}$ & Whole-cell patch clamping & DG & $\begin{array}{l}\downarrow \text { Number of action } \\
\text { potential } \\
\uparrow \text { Rheobase current } \\
\uparrow \text { Negative resting } \\
\text { membrane potential }\end{array}$ & $\begin{array}{l}\text { Improved contextual fear } \\
\text { memory extinction }\end{array}$ \\
\hline $\begin{array}{l}\text { Pousti et al. } \\
\text { (2018) [21] }\end{array}$ & Adult rats (Wistar) & In vivo extracellular recording & DG & $\begin{array}{l}\uparrow \text { Long-term potentiation } \\
\uparrow \text { Paired-pulse ratio } \\
\uparrow \text { Baseline } \\
\text { Prevented long-term de- } \\
\quad \text { pression }\end{array}$ & N/A \\
\hline
\end{tabular}

${ }^{\mathrm{a}}$ The number of spontaneously active neurons recorded per track

facilitates LTD [111] in various stress-induced depressed rodent models.

Conversely, chronic treatment with standard antidepressants prevents stress-induced hippocampal LTD [111] and stress-induced disturbances in synaptic proteins, such as PSD-95 and synapsin I [112]. Considerably, a single dose of ketamine induces fast antidepressant response and restores the
LTP and NMDAR-dependent excitatory postsynaptic current in depressed mice [110]. Altogether, it indicates that altered synaptic plasticity plays a significant role in the depression pathophysiology and, concurrently, represent a potential target for rapid-acting antidepressants.

The effect of adiponectin on modulating synaptic plasticity is summarized in Table 2. At present, bidirectional effects of

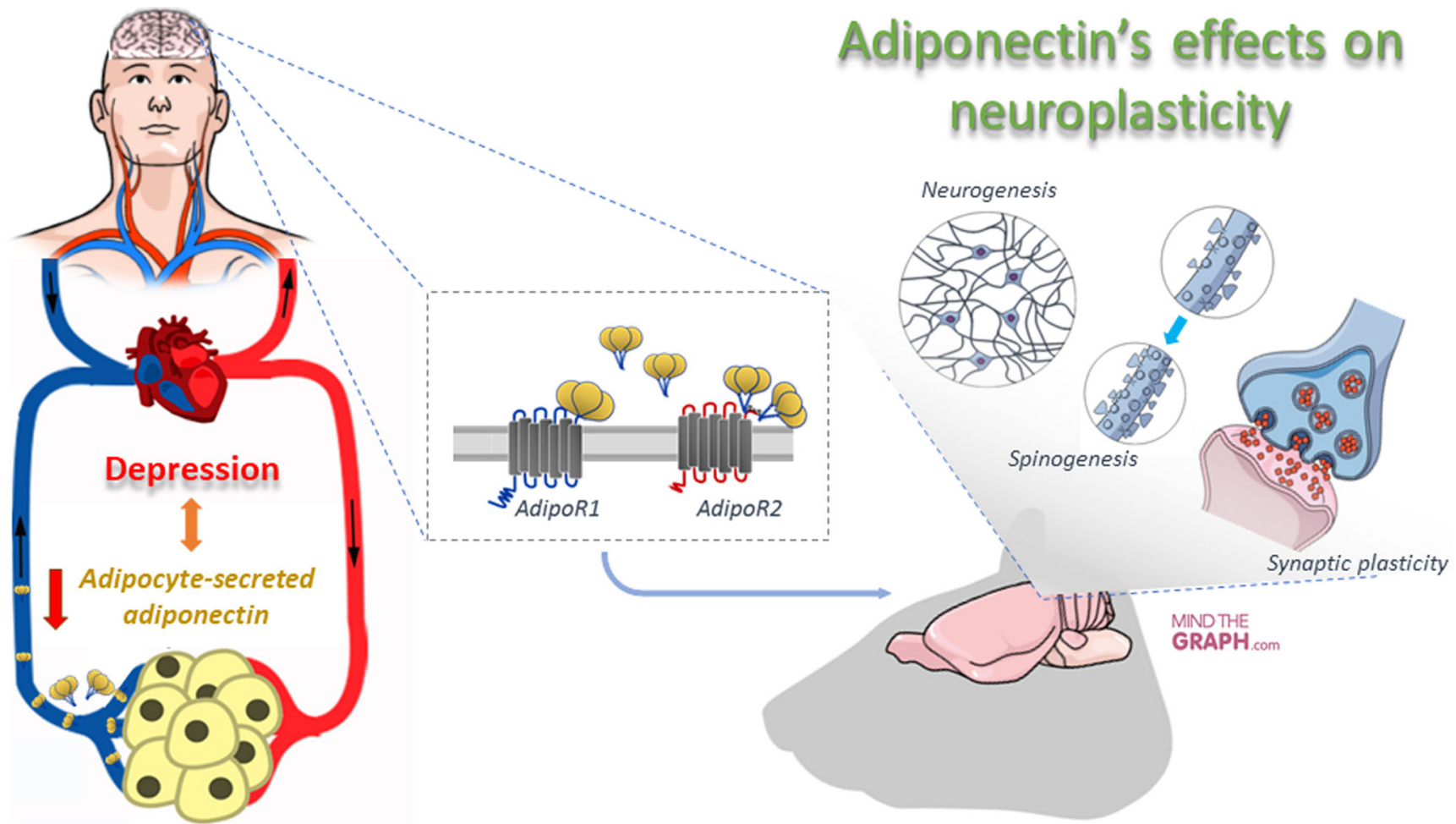

Fig. 2 Proposed beneficial effects of adiponectin in depression. A large body of clinical research have been implicating low peripheral adiponectin levels with depression, and so antidepressant effects of adiponectin may be linked to its effect on promoting neuroplasticity. 
activating the adiponectin receptors on synpatic plasticity have been found. i.c.v. adiponectin infusion increased LTP and prevented LTD in the DG [21]. However, incubation of acute hippocampal slices with AdipoRon further dampened LTP in the Cornu Ammonis 1 (CA1) [22]. Factors affecting the adiponectin receptor-mediated synaptic transmission are not completely understood. The differential expressions of AdipoR1 and AdipoR2 across several brain structures [19] may indicate that they play different roles in synaptic transmission. AdipoRon could increase extinction learning with a decrease in DG neuron intrinsic excitability through an AdipoR2dependent mechanism [30]. Congruently, ventral tegmental area (VTA) infusion of AdipoRon prevented stress-induced anxiety-like behavior with a reduction in dopaminergic neuron activity, which was mediated by AdipoR1-dependent activation [29]. Further investigations on the mechanisms of actions will ultimately demonstrate the adiponectin signaling pathway modulating synaptic plasticity in the brain.

\section{Conclusion and Perspectives}

Antidepressant effects of adiponectin have been shown in depressed rodent models. So far, it has been reported that adiponectin mediates physical exercise and enriched environment-induced antidepressant response, likely due to its promoting effects on adult hippocampus neurogenesis or neurotrophic properties. Animal studies have demonstrated a region-specific effect of AdipoR1 and AdipoR2 on anxietylike behaviour and fear memory extinction, respectively. The findings of AdipoR1/2-dependent modulation of synaptic plasticity and neuronal excitability have suggested differential roles of AdipoR1 and AdipoR2 in the brain. So far, accumulating evidence has suggested that changes in functional neuroplasticity following adiponectin signaling activation could also underly its antidepressant effects as reported from the current literature (Fig. 2).

This is in consonance with the current systemic conceptualization of depression in terms of its neuroplasticity changes [8-10] that, when counteracted, may result in sustained antidepressant responses. Nevertheless, adiponectin is also a metabolic regulator with insulin-sensitizing, anti-inflammatory, and cardioprotective properties, bridging the correlation between depression and metabolic disorders. Hence, it is tempting to think that targeting the adiponergic system may not only induce a rapid and sustained antidepressant effect but also regulate the metabolic dysfunction commonly associated with depression.

Even though experimental studies have just started unraveling the adiponectin mechanisms of action in neuroplasticity, and some antagonisms remain to be explained, the adiponergic system stands as a promising antidepressant target with fast response, small side effects, and capability of improving the comorbid metabolic syndromes.

Funding This work was supported by the Hong Kong Research Council Early Career Scheme (project No. 25100217), General Research Fund (Project No. 15100018), and National Natural Science Foundation of China (Project No.81801346).

\section{Compliance with Ethical Standards}

Conflict of Interest The authors declare that they have no conflict of interest.

Open Access This article is distributed under the terms of the Creative Commons Attribution 4.0 International License (http:// creativecommons.org/licenses/by/4.0/), which permits unrestricted use, distribution, and reproduction in any medium, provided you give appropriate credit to the original author(s) and the source, provide a link to the Creative Commons license, and indicate if changes were made.

\section{References}

1. Vos T, Flaxman AD, Naghavi M, Lozano R, Michaud C, Ezzati $\mathrm{M}$, et al. Years lived with disability (YLDs) for 1160 sequelae of 289 diseases and injuries 1990-2010: a systematic analysis for the Global Burden of Disease Study 2010. Lancet. 2012;380(9859): 2163-2196. Available from: http://linkinghub.elsevier.com/ retrieve/pii/S0140673612617292

2. Smith K (2014) Mental health: a world of depression. Nature 515(7526): 181

3. Gustavsson A, Svensson M, Jacobi F, Allgulander C, Alonso J, Beghi E, Dodel R, Ekman M et al (2011) Cost of disorders of the brain in Europe 2010. Eur Neuropsychopharmacol 21(10):718779. https://doi.org/10.1016/j.euroneuro.2011.08.008

4. Mrazek DA, Hornberger JC, Altar CA, Degtiar I (2014) A review of the clinical, economic, and societal burden of treatmentresistant depression: 1996-2013. Psychiatr Serv 65(8):977-987 Available from: http://psychiatryonline.org/doi/abs/10.1176/appi. ps. 201300059

5. Keller MB, Gelenberg AJ, Hirschfeld RM, Rush AJ, Thase ME, Kocsis JH et al (1998) The treatment of chronic depression, part 2: a double-blind, randomized trial of sertraline and imipramine. J Clin Psychiatry 59(11):598-607 Available from: http://www.ncbi. nlm.nih.gov/pubmed/9862606

6. Trivedi MH, Rush AJ, Wisniewski SR, Nierenberg AA, Warden D, Ritz L, Norquist G, Howland RH et al (2006) Evaluation of outcomes with citalopram for depression using measurementbased care in STAR*D: Implications for clinical practice. Am J Psychiatry 163(1):28-40 Available from: http://psychiatryonline. org/doi/abs/10.1176/appi.ajp.163.1.28

7. Jick H (2004) Antidepressants and the risk of suicidal behaviors. JAMA 292(3):338 Available from: http://jama.jamanetwork.com/ article.aspx?doi=10.1001/jama.292.3.338

8. Marsden WN (2013) Synaptic plasticity in depression: Molecular, cellular and functional correlates. Prog Neuro-Psychopharmacol Biol Psychiatry 43:168-184. https://doi.org/10.1016/j.pnpbp. 2012.12.012

9. Castrén E (2013) Neuronal network plasticity and recovery from depression. JAMA Psychiatry 70(9):983 Available from: http:// archpsyc.jamanetwork.com/article.aspx?doi=10.1001/ jamapsychiatry.2013.1 
10. Manji HK, Quiroz JA, Sporn J, Payne JL, Denicoff K, A Gray N et al (2003) Enhancing neuronal plasticity and cellular resilience to develop novel, improved therapeutics for difficult-to-treat depression. Biol Psychiatry 53(8):707-742 Available from: http://www. ncbi.nlm.nih.gov/pubmed/12706957

11. Peltoniemi MA, Hagelberg NM, Olkkola KT, Saari TI (2016) Ketamine: a review of clinical pharmacokinetics and pharmacodynamics in anesthesia and pain therapy. Clin Pharmacokinet 55(9):1059-1077

12. Zarate CA, Singh JB, Carlson PJ, Brutsche NE, Ameli R, Luckenbaugh DA, Charney DS, Manji HK (2006) A randomized trial of an N-methyl-D-aspartate antagonist in treatment-resistant major depression. Arch Gen Psychiatry 63(8):856 Available from: http://archpsyc.jamanetwork.com/article.aspx?doi=10.1001/ archpsyc.63.8.856

13. Moghaddam B, Adams B, Verma A, Daly D (1997) Activation of glutamatergic neurotransmission by ketamine: a novel step in the pathway from NMDA receptor blockade to dopaminergic and cognitive disruptions associated with the prefrontal cortex. J Neurosci 17(8):2921-2927

14. Li N, Lee B, Liu R-J, Banasr M, Dwyer JM, Iwata M, Li XY, Aghajanian G et al (2010) mTOR-dependent synapse formation underlies the rapid antidepressant effects of NMDA antagonists. Science 329(5994):959-964 Available from: http://www. sciencemag.org/cgi/doi/10.1126/science.1190287

15. Li N, Liu RJ, Dwyer JM, Banasr M, Lee B, Son H, Li XY, Aghajanian G et al (2011) Glutamate N-methyl-D-aspartate receptor antagonists rapidly reverse behavioral and synaptic deficits caused by chronic stress exposure. Biol Psychiatry 69(8):754-761

16. Yang C, Hu Y-M, Zhou Z-Q, Zhang G-F, Yang J-J (2013) Acute administration of ketamine in rats increases hippocampal BDNF and mTOR levels during forced swimming test. Ups J Med Sci 118(1):3-8 Available from: http://www.tandfonline.com/doi/full/ 10.3109/03009734.2012.724118

17. Murrough JW, Abdallah CG, Mathew SJ (2017) Targeting glutamate signalling in depression: Progress and prospects. Nat Rev Drug Discov 16(7):472-486. https://doi.org/10.1038/nrd.2017.16

18. Kubota N, Yano W, Kubota T, Yamauchi T, Itoh S, Kumagai H, Kozono H, Takamoto I et al (2007) Adiponectin stimulates AMPactivated protein kinase in the hypothalamus and increases food intake. Cell Metab 6(1):55-68

19. Liu J, Guo M, Zhang D, Cheng S-Y, Liu M, Ding J, Scherer PE, Liu F et al (2012) Adiponectin is critical in determining susceptibility to depressive behaviors and has antidepressant-like activity. Proc Natl Acad Sci 109(30):12248-12253 Available from: http:// www.pnas.org/lookup/doi/10.1073/pnas.1202835109

20. Zhang D, Wang X, Lu XY (2016) Adiponectin exerts neurotrophic effects on dendritic arborization, spinogenesis, and neurogenesis of the dentate gyrus of male mice. Endocrinology. 157(7):2853-2869

21. Pousti F, Ahmadi R, Mirahmadi F, Hosseinmardi N, Rohampour $\mathrm{K}$ (2018) Adiponectin modulates synaptic plasticity in hippocampal dentate gyrus. Neurosci Lett 662:227-232. https://doi.org/10. 1016/j.neulet.2017.10.042

22. Weisz F, Piccinin S, Mango D, Ngomba RT, Mercuri NB, Nicoletti F, Nisticò R (2017) The role of adiponectin receptors in the regulation of synaptic transmission in the hippocampus. Synapse 71(5):e21964 Available from: http://doi.wiley.com/10.1002/syn. 21964

23. Nicolas S, Debayle D, Béchade C, Maroteaux L, Gay A-S, Bayer P, Heurteaux C, Guyon A et al (2018) Adiporon, an adiponectin receptor agonist acts as an antidepressant and metabolic regulator in a mouse model of depression. Transl Psychiatry 8(1):159. https://doi.org/10.1038/s41398-018-0210-y

24. Okada-Iwabu M, Yamauchi T, Iwabu M, Honma T, Hamagami KI, Matsuda K, Yamaguchi M, Tanabe H et al (2013) A small- molecule AdipoR agonist for type 2 diabetes and short life in obesity. Nature 503(7477):493-499. https://doi.org/10.1038/ nature 12656

25. Ouchi N, Kihara S, Arita Y, Maeda K, Kuriyama H, Okamoto Y, Hotta K, Nishida M et al (1999) Novel modulator for endothelial adhesion molecules: adipocyte-derived plasma protein adiponectin. Circulation 100(25):2473-2476 Available from: http://www.ncbi.nlm.nih.gov/pubmed/10604883

26. Tsao TS, Tomas E, Murrey HE, Hug C, Lee DH, Ruderman NB, Heuser JE, Lodish HF (2003) Role of disulfide bonds in Acrp30/ adiponectin structure and signaling specificity: different oligomers activate different signal transduction pathways. J Biol Chem 278(50):50810-50817

27. Waki H, Yamauchi T, Kamon J, Ito Y, Uchida S, Kita S, Hara K, Hada Y et al (2003) Impaired multimerization of human adiponectin mutants associated with diabetes. Molecular structure and multimer formation of adiponectin. J Biol Chem 278(41): 40352-40363

28. Yamauchi T, Kamon J, Ito Y, Tsuchida A, Yokomizo T, Kita S, Sugiyama T, Miyagishi M et al (2003) Cloning of adiponectin receptors that mediate antidiabetic metabolic effects. Nature 423(6941):762-769 Available from: http://www.nature.com/ articles/nature 01705

29. Sun F, Lei Y, You J, Li C, Sun L, Garza J et al (2018) Adiponectin modulates ventral tegmental area dopamine neuron activity and anxiety-related behavior through AdipoR1. Mol Psychiatry:1-19. https://doi.org/10.1038/s41380-018-0102-9

30. Zhang, Wang X, Wang B, Garza JC, Fang X, Wang J et al (2017) Adiponectin regulates contextual fear extinction and intrinsic excitability of dentate gyrus granule neurons through AdipoR2 receptors. Mol Psychiatry 22(7):1044-1055 Available from: http:/ www.nature.com/doifinder/10.1038/mp.2016.58

31. Berg AH, Combs TP, Scherer PE (2002) ACRP30/adiponectin: an adipokine regulating glucose and lipid metabolism. Trends Endocrinol Metab 13(2):84-89 Available from: http://www.ncbi. nlm.nih.gov/pubmed/11854024

32. Whitehead JP, Richards AA, Hickman IJ, Macdonald GA, Prins JB (2006) Adiponectin - a key adipokine in the metabolic syndrome. Diabetes Obes Metab 8(3):264-280 Available from: http:// doi.wiley.com/10.1111/j.1463-1326.2005.00510.x

33. Ouchi N, Parker JL, Lugus JJ, Walsh K (2011) Adipokines in inflammation and metabolic disease. Nat Rev Immunol 11(2): 85-97 Available from: http://www.nature.com/articles/nri2921

34. Brochu-Gaudreau K, Rehfeldt C, Blouin R, Bordignon V, Murphy BD, Palin MF (2010) Adiponectin action from head to toe. Endocrine. 37(1):11-32

35. Hu E, Liang P, Spiegelman BM (1996) AdipoQ is a novel adiposespecific gene dysregulated in obesity. J Biol Chem 271(18): 10697-10703 Available from: http://www.ncbi.nlm.nih.gov/ pubmed $/ 8631877$

36. Arita Y, Kihara S, Ouchi N, Takahashi M, Maeda K, Miyagawa J, Hotta K, Shimomura I et al (1999) Paradoxical decrease of an adipose-specific protein, adiponectin, in obesity. Biochem Biophys Res Commun 257(1):79-83 Available from: http:// www.ncbi.nlm.nih.gov/pubmed/10092513

37. Sheng T, Yang K (2008) Adiponectin and its association with insulin resistance and type 2 diabetes. J Genet Genomics 35(6): 321-326 Available from: http://linkinghub.elsevier.com/retrieve/ pii/S1673852708600478

38. Herder C, Schmitt A, Budden F, Reimer A, Kulzer B, Roden M et al (2018) Association between pro- and anti-inflammatory cytokines and depressive symptoms in patients with diabetespotential differences by diabetes type and depression scores. Transl Psychiatry 7(11):1 Available from: http://www.ncbi.nlm. nih.gov/pubmed/29520075 
39. Everson-Rose SA, Clark CJ, Wang Q, Guo H, Mancuso P, Kravitz HM, Bromberger JT (2018) Depressive symptoms and adipokines in women: study of women's health across the nation. Psychoneuroendocrinology 97(January):20-27. https://doi.org/ 10.1016/j.psyneuen.2018.07.011

40. Cizza G, Nguyen VT, Eskandari F, Duan Z, Wright EC, Reynolds JC, Ahima RS, Blackman MR et al (2010) Low 24-hour adiponectin and high nocturnal leptin concentrations in a casecontrol study of community-dwelling premenopausal women with major depressive disorder. J Clin Psychiatry 71(08):1079-1087 Available from: http://article.psychiatrist.com/?ContentType= START\&ID=10007024

41. Leo R, Di Lorenzo G, Tesauro M, Cola C, Fortuna E, Zanasi M et al (2006) Decreased plasma adiponectin concentration in major depression. Neurosci Lett 407(3):211-213

42. Diniz BS, Teixeira AL, Campos AC, Miranda AS, Rocha NP, Talib LL, Gattaz WF, Forlenza OV (2012) Reduced serum levels of adiponectin in elderly patients with major depression. $\mathrm{J}$ Psychiatr Res 46(8):1081-1085. https://doi.org/10.1016/j. jpsychires.2012.04.028

43. Laake JPS, Stahl D, Amiel SA, Petrak F, Sherwood RA, Pickup JC, Ismail K (2014) The association between depressive symptoms and systemic inflammation in people with type 2 diabetes: findings from the South London diabetes study. Diabetes Care 37(8):2186-2192

44. Herder C, Fürstos JF, Nowotny B, Begun A, Strassburger K, Müssig K, Szendroedi J, Icks A et al (2017) Associations between inflammation-related biomarkers and depressive symptoms in individuals with recently diagnosed type 1 and type 2 diabetes. Brain Behav Immun 61:137-145. https://doi.org/10.1016/j.bbi. 2016.12.025

45. Yang J, Du G, Wang J, Chen J, Yang C, Li J et al (2018) Reduced serum adiponectin level and risk of poststroke depression in patients with ischemic stroke. J Stroke Cerebrovasc Dis (32)

46. Fábregas BC, Vieira ÉLM, Moura AS, Carmo RA, Ávila RE, Abreu MNS, Prossin AR, Teixeira AL (2016) A follow-up study of 50 chronic hepatitis $\mathrm{C}$ patients: adiponectin as a resilience biomarker for major depression. Neuroimmunomodulation. 23(2): 88-97

47. Tunçel ÖK, Akbaș S, Bilgici B (2016) Increased ghrelin levels and unchanged adipocytokine levels in major depressive disorder. J Child Adolesc Psychopharmacol 26(8):733-739 Available from: http://online.liebertpub.com/doi/10.1089/cap.2015.0149

48. Rebelo F, Farias DR, Struchiner CJ, Kac G (2016) Plasma adiponectin and depressive symptoms during pregnancy and the postpartum period: a prospective cohort study. J Affect Disord 194:171-179. https://doi.org/10.1016/j.jad.2016.01.012

49. Cao B, Chen Y, Brietzke E, Cha D, Shaukat A, Pan Z, Park C, Subramaniapillai M et al (2018) Leptin and adiponectin levels in major depressive disorder: a systematic review and meta-analysis. J Affect Disord 238(April):101-110. https://doi.org/10.1016/j.jad. 2018.05.008

50. Ghanei Gheshlagh R, Parizad N, Sayehmiri K. The relationship between depression and metabolic syndrome: systematic review and meta-analysis study. Iran Red Crescent Med J. 2016;InPress(InPress). Available from: http://ircmj.com/en/ articles $/ 55224 . \mathrm{html}$

51. Nakamura K, Fuster JJ, Walsh K (2014) Adipokines: a link between obesity and cardiovascular disease. J Cardiol 63(4):250 259 Available from: https://linkinghub.elsevier.com/retrieve/pii/ S0914508713003559

52. Kadowaki $\mathrm{T}$ (2006) Adiponectin and adiponectin receptors in insulin resistance, diabetes, and the metabolic syndrome. J Clin Invest 116(7):1784-1792 Available from: http://www.who.int/ $\mathrm{hiv} /$ pub/malecircumcision/neonatal_child_MC_UNAIDS.pdf
53. Tang M, Jiang P, Li H, Liu Y, Cai H, Dang R, Zhu W, Cao L (2015) Fish oil supplementation alleviates depressant-like behaviors and modulates lipid profiles in rats exposed to chronic unpredictable mild stress. BMC Complement Altern Med 15(1):239. https://doi.org/10.1186/s12906-015-0778-1

54. Nicolas S, Veyssière J, Gandin C, Zsürger N, Pietri M, Heurteaux C, Glaichenhaus N, Petit-Paitel A et al (2015) Neurogenesisindependent antidepressant-like effects of enriched environment is dependent on adiponectin. Psychoneuroendocrinology 57:7283. https://doi.org/10.1016/j.psyneuen.2015.03.017

55. Guo M, Li C, Lei Y, Xu S, Zhao D, Lu X-Y (2017) Role of the adipose PPAR $\gamma$-adiponectin axis in susceptibility to stress and depression/anxiety-related behaviors. Mol Psychiatry 22(7): 1056-1068 Available from: http://www.nature.com/doifinder/10. 1038/mp.2016.225

56. Chen YC, Lin WW, Chen YJ, Mao WC, Hung YJ (2010) Antidepressant effects on insulin sensitivity and proinflammatory cytokines in the depressed males. Mediat Inflamm 2010:1-7

57. Weber-Hamann B, Kratzsch J, Kopf D, Lederbogen F, Gilles M, Heuser I, Deuschle M (2007) Resistin and adiponectin in major depression: the association with free cortisol and effects of antidepressant treatment. J Psychiatr Res 41(3-4):344-350

58. Pinar M, Gulsun M, Tasci I, Erdil A, Bolu E, Acikel C, Doruk A (2008) Maprotiline induced weight gain in depressive disorder: changes in circulating ghrelin and adiponectin levels and insulin sensitivity. Prog Neuro-Psychopharmacol Biol Psychiatry. 32(1): 135-139

59. Narita K, Murata T, Takahashi T, Kosaka H, Omata N, Wada Y (2006) Plasma levels of adiponectin and tumor necrosis factoralpha in patients with remitted major depression receiving longterm maintenance antidepressant therapy. Prog NeuroPsychopharmacol Biol Psychiatry 30(6):1159-1162

60. Herder C, Schmitt A, Budden F, Reimer A, Kulzer B, Roden M, Haak T, Hermanns N (2018) Longitudinal associations between biomarkers of inflammation and changes in depressive symptoms in patients with type 1 and type 2 diabetes. Psychoneuroendocrinology 91(October 2017):216-225. https:// doi.org/10.1016/j.psyneuen.2018.02.032

61. Bouskila M, Pajvani UB, Scherer PE (2005) Adiponectin: a relevant player in PPAR $\gamma$-agonist-mediated improvements in hepatic insulin sensitivity? Int J Obes 29:S17-S23

62. Yau SY, Li A, Hoo RLC, Ching YP, Christie BR, Lee TMC, Xu A, So KF (2014) Physical exercise-induced hippocampal neurogenesis and antidepressant effects are mediated by the adipocyte hormone adiponectin. Proc Natl Acad Sci U S A 111(44): 15810-15815 Available from: http://www.pnas.org/cgi/doi/10. 1073/pnas. 1415219111

63. Chabry J, Nicolas S, Cazareth J, Murris E, Guyon A, Glaichenhaus N, Heurteaux C, Petit-Paitel A (2015) Enriched environment decreases microglia and brain macrophages inflammatory phenotypes through adiponectin-dependent mechanisms: relevance to depressive-like behavior. Brain Behav Immun 50: 275-287 Available from: https://linkinghub.elsevier.com/ retrieve/pii/S0889159115004134

64. Li A, Yau SY, Machado S, Yuan T-F, So K-F (2015) Adult neurogenic and antidepressant effects of adiponectin: a potential replacement for exercise? CNS Neurol Disord - Drug Targets 14(9): 1129-1144 Available from: http://www.eurekaselect.com/ openurl/content.php?genre $=$ article $\&$ issn $=1871-5273 \&$ volume $=$ 14\&issue $=9$ \&spage $=1129$

65. Yau SY, Li A, Xu A, So K (2015) Fat cell-secreted adiponectin mediates physical exercise-induced hippocampal neurogenesis: an alternative anti-depressive treatment? Neural Regen Res 10(1):7 Available from: http://www.nrronline.org/text.asp?2015/10/1/7/ 150637 
66. Zhou Q, Xiang H, Li A, Lin W, Huang Z, Guo J, et al (2018) Activating adiponectin signaling with exogenous AdipoRon reduces myelin lipid accumulation and suppresses macrophage recruitment after spinal cord injury. J Neurotrauma. neu.2018.5783. Available from: https://www.liebertpub.com/doi/10.1089/neu. 2018.5783

67. Zhang N, Wei W-Y, Liao H-H, Yang Z, Hu C, Wang S, Deng W, Tang QZ (2018) AdipoRon, an adiponectin receptor agonist, attenuates cardiac remodeling induced by pressure overload. J Mol Med 96(12):1345-1357 Available from: http://link.springer.com/ 10.1007/s00109-018-1696-8

68. Zhao M, Momma S, Delfani K, Carlen M, Cassidy RM, Johansson CB, Brismar H, Shupliakov O et al (2003) Evidence for neurogenesis in the adult mammalian substantia nigra. Proc Natl Acad Sci 100(13):7925-7930 Available from: http://www. pnas.org/cgi/doi/10.1073/pnas.1131955100

69. Takemura NU (2005) Evidence for neurogenesis within the white matter beneath the temporal neocortex of the adult rat brain. Neuroscience 134(1):121-132 Available from: http://linkinghub. elsevier.com/retrieve/pii/S0306452205004008

70. Bernier PJ, Bedard A, Vinet J, Levesque M, Parent A (2002) Newly generated neurons in the amygdala and adjoining cortex of adult primates. Proc Natl Acad Sci 99(17):11464-11469 Available from: http://www.pnas.org/cgi/doi/10.1073/pnas. 172403999

71. Bédard A, Gravel C, Parent A (2006) Chemical characterization of newly generated neurons in the striatum of adult primates. Exp Brain Res 170(4):501-512 Available from: http://link.springer. com/10.1007/s00221-005-0233-5

72. Altman J (1969) Autoradiographic and histological studies of postnatal neurogenesis. J Comp Neurol 137(4):433-457

73. Altman J (1963) Autoradiographic investigation of cell proliferation in the brains of rats and cats. Anat Rec 145(4):573-591 Available from: http://doi.wiley.com/10.1002/ar.1091450409

74. Spalding KL, Bhardwaj RD, Buchholz BA, Druid H, Frisén J (2005) Retrospective birth dating of cells in humans. Cell 122(1):133-143 Available from: http://linkinghub.elsevier.com/ retrieve/pii/S0092867405004083

75. Paton JA, Nottebohm FN (1984) Neurons generated in the adult brain are recruited into functional circuits. Science 225(4666): 1046-1048 Available from: http://www.ncbi.nlm.nih.gov/ pubmed/6474166

76. Goldman SA, Nottebohm F (1983) Neuronal production, migration, and differentiation in a vocal control nucleus of the adult female canary brain. Proc Natl Acad Sci U S A 80(8):2390 2394 Available from: http://www.ncbi.nlm.nih.gov/pubmed/ 6572982

77. Cameron HA, McKay RD (2001) Adult neurogenesis produces a large pool of new granule cells in the dentate gyrus. J Comp Neurol 435(4):406-417 Available from: http://www.ncbi.nlm. nih.gov/pubmed/11406822

78. Shen X, Reus LM, Cox SR, Adams MJ, Liewald DC, Bastin ME, Smith DJ, Deary IJ et al (2017) Subcortical volume and white matter integrity abnormalities in major depressive disorder: findings from UK Biobank imaging data. Sci Rep 7(1):5547. https:// doi.org/10.1038/s41598-017-05507-6

79. Warner-Schmidt JL, Duman RS (2006) Hippocampal neurogenesis: opposing effects of stress and antidepressant treatment. Hippocampus 16(3):239-249 Available from: http://doi. wiley.com/10.1002/hipo.20156

80. Perera TD, Coplan JD, Lisanby SH, Lipira CM, Arif M, Carpio C, Spitzer G, Santarelli L et al (2007) Antidepressant-induced neurogenesis in the hippocampus of adult nonhuman primates. $\mathrm{J}$ Neurosci 27(18):4894-4901 Available from: http://www. jneurosci.org/cgi/doi/10.1523/JNEUROSCI.0237-07.2007
81. Perera TD, Dwork AJ, Keegan KA, Thirumangalakudi L, Lipira CM, Joyce N, Lange C, Higley JD et al (2011) Necessity of hippocampal neurogenesis for the therapeutic action of antidepressants in adult nonhuman primates. Kato T, editor. PLoS One 6(4):e17600 Available from: http://dx.plos.org/10.1371/journal. pone. 0017600

82. Anacker C, Zunszain PA, Cattaneo A, Carvalho LA, Garabedian MJ, Thuret S, Price J, Pariante CM (2011) Antidepressants increase human hippocampal neurogenesis by activating the glucocorticoid receptor. Mol Psychiatry 16(7):738-750 Available from: http://www.nature.com/articles/mp201126

83. Malberg JE, Eisch AJ, Nestler EJ, Duman RS (2000) Chronic antidepressant treatment increases neurogenesis in adult rat hippocampus. J Neurosci 20(24):9104-9110 Available from: http:// www.jneurosci.org/lookup/doi/10.1523/JNEUROSCI.20-2409104.2000

84. Yau SY, Lee THY, Li A, Xu A, So KF (2018) Adiponectin mediates running-restored hippocampal neurogenesis in streptozotocin-induced type 1 diabetes in mice. Front Neurosci 12(OCT):1-10

85. Zhang D, Guo M, Zhang W, Lu XY (2011) Adiponectin stimulates proliferation of adult hippocampal neural stem/progenitor cells through activation of $\mathrm{p} 38$ mitogen-activated protein kinase (p38MAPK)/glycogen synthase kinase $3 \beta($ GSK- $3 \beta) / \beta$-catenin signaling cascade. J Biol Chem 286(52):44913-44920

86. van Praag H, Kempermann G, Gage FH (1999) Running increases cell proliferation and neurogenesis in the adult mouse dentate gyrus. Nat Neurosci 2(3):266-270 Available from: http://www. nature.com/articles/nn0399 266

87. van Praag H, Christie BR, Sejnowski TJ, Gage FH (1999) Running enhances neurogenesis, learning, and long-term potentiation in mice. Proc Natl Acad Sci U S A 96(23):13427-13431 Available from: http://linkinghub.elsevier.com/retrieve/pii/ S1353485813700862

88. Lafenetre P, Leske O, Wahle P, Heumann R (2011) The beneficial effects of physical activity on impaired adult neurogenesis and cognitive performance. Front Neurosci 5(APR):1-8

89. Vaynman S, Ying Z, Gomez-Pinilla F (2004) Hippocampal BDNF mediates the efficacy of exercise on synaptic plasticity and cognition. Eur J Neurosci 20(10):2580-2590

90. van Praag H (2009) Exercise and the brain: something to chew on. Trends Neurosci 32(5):283-290 Available from: http://sboc.org. br/revista-sboc/pdfs/34/artigo3.pdf

91. Snigdha S, de Rivera C, Milgram NW, Cotman CW (2014) Exercise enhances memory consolidation in the aging brain. Front Aging Neurosci 6:3 Available from: http://www.ncbi.nlm. nih.gov/pubmed/24550824

92. van Praag H, Shubert T, Zhao C, Gage FH (2005) Exercise enhances learning and hippocampal neurogenesis in aged mice. $\mathrm{J}$ Neurosci 25(38):8680-8685 Available from: http://www.ncbi. nlm.nih.gov/pubmed/16177036

93. Langdon KD, Corbett D (2012) Improved working memory following novel combinations of physical and cognitive activity. Neurorehabil Neural Repair 26(5):523-532 Available from: http://journals.sagepub.com/doi/10.1177/1545968311425919

94. McEwen BS, Liston C (2017) In: Chao MV (ed) Mediators of glucocorticoid-regulated adaptive plasticity, vol 1. Oxford University Press, Oxford Available from: http:// oxfordhandbooks.com/view/10.1093/oxfordhb/9780190635374. 001.0001/oxfordhb-9780190635374-e-3

95. Duman RS, Aghajanian GK. Synaptic dysfunction in depression: potential therapeutic targets. Science (80- ) 2012;338(6103):6872. Available from: http://www.sciencemag.org/cgi/doi/10.1126/ science.1222939

96. von Bohlen, Halbach O (2009) Structure and function of dendritic spines within the hippocampus. Ann Anat - Anat Anzeiger (6): 
518-531 Available from: http://linkinghub.elsevier.com/retrieve/ pii/S0940960209001228

97. Sousa N, Lukoyanov NV, Madeira MD, Almeida OF, PaulaBarbosa MM (2000) Reorganization of the morphology of hippocampal neurites and synapses after stress-induced damage correlates with behavioral improvement. Neuroscience 97(2):253-266 Available from: http://www.ncbi.nlm.nih.gov/pubmed/10799757

98. Castañeda P, Muñoz M, García-Rojo G, Ulloa JL, Bravo JA, Márquez R, García-Pérez MA, Arancibia D et al (2015) Association of N-cadherin levels and downstream effectors of rho GTPases with dendritic spine loss induced by chronic stress in rat hippocampal neurons. J Neurosci Res 93(10):1476-1491 Available from: http://doi.wiley.com/10.1002/jnr.23602

99. Chen Y, Kramár EA, Chen LY, Babayan AH, Andres AL, Gall CM, Lynch G, Baram TZ (2013) Impairment of synaptic plasticity by the stress mediator CRH involves selective destruction of thin dendritic spines via RhoA signaling. Mol Psychiatry 18(4):485496 Available from: http://www.ncbi.nlm.nih.gov/pubmed/ 22411227

100. Pittenger C, Duman RS (2008) Stress, depression and neuroplasticity: a convergence of mechanisms. Neuropsychopharmacology 33(1):88-109 Available from: http://www.nature.com/articles/1301574

101. Duman RS, Aghajanian GK, Sanacora G, Krystal JH (2016) Synaptic plasticity and depression: new insights from stress and rapid-acting antidepressants. Nat Med 22(3):238-249. https://doi. org/10.1038/nm.4050

102. Popoli M, Yan Z, McEwen BS, Sanacora G (2012) The stressed synapse: the impact of stress and glucocorticoids on glutamate transmission. Nat Rev Neurosci 13(1):22-37 Available from: http://www.nature.com/articles/nrn3138

103. Christoffel DJ, Golden SA, Russo SJ (2011) Structural and synaptic plasticity in stress-related disorders. Rev Neurosci 22(5): 535-549 Available from: https://www.degruyter.com/view/j/ revneuro.2011.22.issue-5/rns.2011.044/rns.2011.044.xml

104. Yoon G, Shah SA, Ali T, Kim MO (2018) The adiponectin homo$\log$ osmotin enhances neurite outgrowth and synaptic complexity via AdipoR1/NgR1 signaling in Alzheimer's disease. Mol Neurobiol:1-14
105. Schmaal L, Veltman DJ, Van Erp TGM, Smann PG, Frodl T, Jahanshad N et al (2016) Subcortical brain alterations in major depressive disorder: findings from the ENIGMA major depressive disorder working group. Mol Psychiatry 21(6):806-812

106. Kang HJ, Voleti B, Hajszan T, Rajkowska G, Stockmeier CA, Licznerski P, Lepack A, Majik MS et al (2012) Decreased expression of synapse-related genes and loss of synapses in major depressive disorder. Nat Med 18(9):1413-1417. https://doi.org/10. 1038/nm.2886

107. Citri A, Malenka RC (2008) Synaptic plasticity: multiple forms, functions, and mechanisms. Neuropsychopharmacology. 33(1): $18-41$

108. Bath KG, Russo SJ, Pleil KE, Wohleb ES, Duman RS, Radley JJ (2017) Circuit and synaptic mechanisms of repeated stress: perspectives from differing contexts, duration, and development. Neurobiol Stress 7:137-151. https://doi.org/10.1016/j.ynstr.2017. 05.001

109. Alfarez DN, Joëls M, Krugers HJ (2003) Chronic unpredictable stress impairs long-term potentiation in rat hippocampal CA1 area and dentate gyrus in vitro. Eur J Neurosci 17(9):1928-1934

110. Yang Y, Ju W, Zhang H, Sun L (2018) Effect of ketamine on LTP and NMDAR EPSC in hippocampus of the chronic social defeat stress mice model of depression. Front Behav Neurosci 12(October):1-11 Available from: https://www.frontiersin.org/article/10.3389/fnbeh.2018.00229/full

111. Holderbach R, Clark K, Moreau JL, Bischofberger J, Normann C (2007) Enhanced long-term synaptic depression in an animal model of depression. Biol Psychiatry 62(1):92-100

112. Li XL, Yuan YG, Xu H, Wu D, Gong WG, Geng LY et al (2015) Changed synaptic plasticity in neural circuits of depressive-like and escitalopram-treated rats. Int J Neuropsychopharmacol 18(10):1-12

Publisher's Note Springer Nature remains neutral with regard to jurisdictional claims in published maps and institutional affiliations. 